\title{
Direct Liquefaction of High-Sulfur Coals: Effects of the Catalyst, the Solvent, and the Mineral Matter
}

\author{
Belgin Gözmen, Levent Artok,` Gaye Erbatur, and Oktay Erbatur* \\ Department of Chemistry, Çukurova University, Adana 01330, Turkey
}

Received November 13, 2001

\begin{abstract}
Two low-rank coals with high sulfur contents (Gediz subbituminous coal: 7.6 wt \% S:dry basis. Çayirhan lignite: $5.7 \mathrm{wt} \%$ S:dry basis.) were subjected to hydroliquefaction. Liquefaction conditions included dry or solvent mediated runs under pressurized hydrogen without added catalyst or with the impregnated catalyst precursor ammonium heptamolybdate (AHM). Gediz coal having higher sulfur content gave $90 \%$ conversion in the absence of catalyst and solvent. Maximum conversion (98\%) and maximum oil + gas yield (70\%) from this coal were obtained by impregnating $\mathrm{AHM}$ onto coal and carrying out liquefaction in $\mathrm{H}_{2}$ /tetral in system at $450{ }^{\circ} \mathrm{C}$ for 30 min. Under the same conditions, Çayirhan lignite gave $85 \%$ conversion and $70.5 \%$ oil + gas yield. The superior hydrodesulfurization effect of impregnated AHM on the oil fraction when used in the absence of solvent (less than $0.1 \% \mathrm{~S}$ in lignite's oil and less than $1 \% \mathrm{~S}$ in subbituminous coal's oil following one-stage hydrogenation) is a promising finding of this work. AHM was found to be much more effective in liquefaction of Çayirhan lignite and this has been ascribed to the well-dispersion of AHM throughout this lignite's structure via a cation-exchange mechanism through oxygen functionalities. Strong evidence for the catalytic effect of clay minerals in coal structure on char-forming reactions during liquefaction was observed by making use of liquefaction reactions of demineralized coal samples. It was also observed that tetralin had a retarding effect on the condensation and subsequent cross-linking reactions.
\end{abstract}

\section{Introduction}

Coals when subjected to direct liquefaction by catalytic hydrogenation, yield valuable organic products to be utilized as feedstocks in various processes, one of which is the possibility of being used in the preparation of jet fuels of high thermal stability. ${ }^{1-4}$ In direct catalytic hydroliquefaction of coals, the factors which are considered to be important in determining the quality and quantity of liquid fuels which will be produced and in determining the economic feasibility of the process are the type of the coal to be processed, the catalyst, the ratio of the amount of hydrogen gas and solvent to the amount of liquid fuels produced, and of course the temperature and the pressure of the process. In general, most of the covalent bonds in coal structure cleave at temperatures between 375 and $450{ }^{\circ} \mathrm{C}$ and therefore direct hydroliquefaction processes use temperatures around these values. One should mention that if the treated coal is in the low rank range having high carboxyl and/or sulfidic type of functional groups, then covalent bond breakage starts at significantly lower

* Corresponding author. Tel.: +90-322-3386540. Fax: +90-3223386070. E-mail: erbatur@mail.cu.edu.tr.

+ Present address: Department of Chemistry, Izmir Institute of Technology, Urla 35437, Izmir, Turkey.

(1) Song, C.; Schobert, H. H. Fuel Process. Technol. 1993, 34, 15796.

(2) Song, C.; Schobert, H. H. Fuel 1996, 75, 724-736.

(3) Song, C.; Eser, S.; Schobert, H. H.; Hatcher, P. G. Energy Fuels 1993, 7, 234-243.

(4) Burgess, C. E.; Schobert, H. H. Fuel Process. Technol. 2000, 64, temperatures..$^{5-7}$ The main reactions which take place during liquefaction are thermolysis, hydrogenation, dealkylation, desulfurization, denitrogenation, dehydration, cleaving of cyclic hydrocarbon structures into openchain hydrocarbons, and condensation reactions. Except the last one, the rest of the reactions have to take place for an effective liquefaction though cleaving of alicyclic structures will also be a disadvantage if the final aim is to obtain an oil appropriate for preparing thermally stable jet fuels. On the other hand, retrogressive reactions taking place when quenching of active radical sites by hydrogen transfer is not fast enough, result in the formation of larger and refractory organic structures. ${ }^{8-11}$

The coal liquids are also used as solvent in coal liquefaction processes. These liquids in general, have two to four condensed rings and are very effective hydrogen shuttlers. ${ }^{12,13}$ These solvents are generally

(5) Suuberg, E. M.; Lee, D.; Larsen, J . W. Fuel 1985, 64, 16681671

(6) Solomon, P. R.; Serio, M. A.; Despande, G. V.; Kroo, E. Energy Fuels 1990, 4, 42-54.

(7) Garcia, A. B.; Schobert, H. H. Fuel Process. Technol. 1990, 24, $179-185$.

(8) Huang, L.; Schobert, H. H. Coal Science; Pajares, J . A., Tascon, J. M. D., Eds.; Coal Science and Technology 24; Elsevier Science: Amsterdam, 1995; p 1243.

(9) Glenn, R. A.; De Walt, C. W., J r. Fuel 1953, 32, 157-168.

(10) Wiser, W. H. Fue 1968, 47, 475-485.

(11) Bockrath, B. C. In Coal Science Vol. 2; Gorbaty, M. L., Larsen, J . W., Wender, I. Eds.; Academic Press: New York, 1983; pp 65-124. (12) Gorbaty, M. L. Coal Liquefaction. A Research Needs AssesmentTechnical Background; Department of Energy, Coal Liquefaction Research Needs-Pannel Assesment, Final Report; Department of Energy: Washington, DC, 1989; Vol. 2, Chapter 4.

(13) Sullivan, R. F. Upgrading Coal Liquids; ACS Symposium Series 139; American Chemical Society: Washington, DC, 1981; pp 239-251. 
used at temperatures between 200 and $400{ }^{\circ} \mathrm{C}$ and are hydrogenated while being recycled to liquefaction reactor. ${ }^{14-19}$ It is now certain that these solvents are effective in quenching active radicals which are formed during thermolysis of various covalent bonds in coal structures, but there is al so a debate on solvent's effect in thermolysis reactions as well. While a group of researchers argue that solvent-derived cycl ohexadi enyl radicals induce cleavage of relatively strong covalent bonds, others find this argument quite debatable especially at short liquefaction times. ${ }^{20-27}$ Solvents also enhance various reactions during coal liquefaction via the solvation effect. The hydrogen donor solvents swell the coal structure so that efficient interactions of coal reactive sites with both hydrogen donating solvents and with catalyst precursors dispersed in the reaction medium are attained. ${ }^{28}$ It has also been proposed that structures such as quinoline and primary amines in coal solvents not only enhanced swelling, but also took part in cleaving relatively strong bonds. ${ }^{29,30}$

Hydrogen gas is also an important reactant in direct liquefaction reactions. Together with solvent and catalyst, it plays the major role in direct liquefaction of coal. The main functions of hydrogen gas in coal liquefaction are quenching of active radicals which are formed during thermolysis reactions, enhancing the cleavage of $\mathrm{C}_{\mathrm{ar}}-\mathrm{C},{ }^{20} \mathrm{C}_{\mathrm{ar}}-\mathrm{O},{ }^{31}$ and other si milar coval ent bonds and hydrogenating the solvent molecules in-situ and while being recycled to the liquefaction reactor.

In some cases, addition of $\mathrm{H}_{2} \mathrm{~S}$ to the reactor also enhances liquefaction of coals. ${ }^{17-19,32-37}$ It has been proposed that $\mathrm{H}_{2} \mathrm{~S}$ is also effective in cleaving some strong bonds, ${ }^{38}$ in removal of nitrogen from coal struc-

(14) Kuhlman, E. J .; J ung, D. Y.; Guptill, R. P.; Dyke, C. A.; Zank, H. K. Fue 1986, 64, 1552-1557.

(15) Sato, Y.; Yamato, T.; Kamo, T.; Inabo, A.; Miki, K.; Saito, I. Energy Fuels 1991, 5, 98-102.

(16) Anderson, R. K.; Lim, S. C.; Ni, H.; Derbyshire, F.J .; Givens,

E. N. Fuel Process. Technol. 1995, 45, 109-122.

(17) Demirel, B.; Givens, E. N. Energy Fuels 1998, 12, 607-611.

(18) Zhan, X.; Givens, E. N. Catal. Today 1999, 50, 141-148.

(19) Demirel, B.; Givens, E. N. Fuel 2000, 79, 1975-1980.

(20) Vernon, L. W. Fue 1980, 59, 102-106.

(21) Mcmillen, D. F.; Malhotra, R.; Chang, S. J .; Hum, G. P. Energy Fuels 1987, 1, 193-198.

(22) Mcmillen, D. F.: Malhotra, R.: Chang, S. J.: Oiger, W. C. Nigenda, S. E.; Fleming, R. H. Fuel 1987, 66, 1611-1620.

(23) Mcmillen, D. F.; Malhotra, R.; Tse, D. S. Energy Fuels 1991, 5, $179-187$.

(24) Malhotra, R.; Mcmillen, D. F. Energy Fuels 1990, 4, 184-193. (25) Malhotra, R.; Mcmillen, D. F. Energy Fuels 1993, 7, 227-233. 590

(26) Kamiya, K.; Ogata, E.; Goto, K.; Nomi, T. Fuel 1986, 65, 586-

(27) Curran, G. P.; Struct, R. T.; Gorin, E. Prepr. Pap.-Am. Chem. Soc., Div. Pet. Chem. 1966, 130-148.

(28) Eser, S.; J enkins, R. G.; Wei, G.; Schobert, H. H.; J oseph, J . T.

Fuel 1991, 70, 1445-1455.

(29) Kazimi, F.; Chen, W. Y.; Chen, J . K.; Whitney, R. R.; Zimny, B. Prepr. Pap.-Am. Chem. Soc., Div. Fue Chem. 1985, 30, 4402.

(30) Togaya, H.; Sufai, J .; Onuki, M.; Chiba, K. Energy Fuels 1987,

$1,397-401$

(31) Artok, L.; Erbatur, O.; Schobert, H. H. Fuel Process. Technol. 1996, 47, 153-176.

(32) Abdel-Baset, M. B.; Ratcliffe, C. T. Prepr. Pap.-Am. Chem. Soc., Div. Fuel Chem. 1980, 25, 1-7.

(33) Baldwin, R. M.; Vinciguerra, S. Fuel 1983, 62, 498-501.

(34) Artok, L.; Davis, A.; Mitchell, G. D.; Schobert, H. H. Energy

Fuels 1993, 7, 67-77.

(35) Demirel, B.; Givens, E. N. Catal. Today 1999, 50, 149-158.

(36) Demirel, B.; Fang, S.; Givens, E. N. Appl. Catal. A: Gen. 2000,

201, 177-190.

(37) Demirel, B.; Givens, E. N. Fuel Process. Technol. 2000, 64, 177187.

(38) Hei, R. D.; Sweeny, P. G.; Stenberg, V. I. Fued 1986, 65, 577- tures $^{39}$ and in improving the catalytic effect of mineral matter in coal by converting iron compounds into iron sulfide forms. ${ }^{33,40-43}$

Hydroliquefaction catalysts are considered to be effective in hydrocracking reactions, in quenching of active radicals which are formed due to the thermolysis reactions, in removal of heteroatoms in coal structures, in hydrogenating the appropriate sites in coal structures, and in hydrogenating the solvent molecules by activating the molecular hydrogen and/or solvent. They can be classified into two main groups: supported catalysts and dispersed catalysts. The former group has been reviewed by Derbyshire. ${ }^{44} \mathrm{~A}$ general review on coal liquefaction catalysts was done by Anderson. ${ }^{45}$ The catalytic effect of mineral matter in coals in liquefaction was reviewed by Schobert.46 Most of the work on coal liquefaction catalysts up to 1990 were cited in these three reviews. Research on development and use of coal liquefaction catalysts in the past decade were still continuing. ${ }^{47-56}$ The superiority of using water soluble molybdenum compounds in coal liquefaction as catalyst precursors by impregnating onto coal particles has been well documented. ${ }^{16-19,35-37,44,57-65}$ Pilot plant studies have also demonstrated that using dispersed molybdenum catalysts were very efficient in primary liquefaction (dissolution) of coal, particularly of low-rank coals such as subbituminous coals and lignites. ${ }^{66-70}$

(39) Satterfield, C. N.; Yang, S. H. Ind. Eng. Chem. Process Des. Dev. 1981, 23, 20-25.

(40) Anderson, R. R.; Bockrath, B. C. Fuel 1984, 63, 329-333.

(41) Wilson, W. G.; Hei, R.; Riskedahl, D.; Stenberg, V. I. Fuel 1985, $64,128-130$

(42) Trewhella, M. J .; Grint, A. Fuel 1987, 66, 1315-1320.

(43) Youtcheff, J. S.; Given, P. H. Fue 1982, 61, 980-987.

(44) Derbyshire, F. J . Catalysis in Coal Liquefaction. IEACR/08; IEA Coal Research: London, U.K., 1988.

(45) Anderson, L. L. Clean Utilization of Coal; NATO ASI Series 370; Kluwer Academic Publishers: Dordrecht, 1992; pp 49-64.

(46) Schobert, H. H. Clean Utilization of Coal; NATO ASI Series

370; Kluwer Academic Publishers: Dordrecht, 1992; pp 65-74.

(47) Zhao, J .; Feng, Z.; Huggins, F. E.; Huffman, G. P. Energy Fuels

1996, 10, 250-253.

(48) Shah, N.; Zhao, J .; Huggins, F. E.; Huffman, G. P. Energy Fuels 1996, 10, 417-420.

(49) I kenaga, N.; Sakoda, T.; Matsui; T.; Ohno, K.; Suzuki, T. Energy Fuels 1997, 11, 183-189.

(50) Kotanigawa, T.; Yamamoto, M.; Sasaki, M.; Wang, N.; Nagaishi, H.; Yoshida, T. Energy Fuels 1997, 11, 190-193.

(51) Cugini, A. V.: Rothenberger, K. S.; Ciocco, M. V.; Veloski, G. V. Energy Fuels 1997, 11, 213-220.

(52) Sakanishi, K.; Hasuo, H.-u.; Mochida, I. Energy Fuels 1998, 12, 284-288.

(53) Sharma, R. K.; MacFadden, J . S.; Stiller, A. H.; Dadyburjor, D. B. Energy Fuels 1998, 12, 312-319.

(54) Priyanto, U.; Sakanishi, K.; Mochida, I. Energy Fuels 2000, 14 801-805.

(55) Qian, V.; Shirai, H.; I fuku, M.; Ishihara, A.; Kabe, T. Energy Fuels 2000, 14, 1205-1211.

(56) Mochida, I.; Sakanishi, K. Fuel 2000, 79, 221-228.

(57) Derbyshire, F. J .; Hager, T. Fuel 1994, 73, 1087-1092.

(58) Weller, S. W. In Chemistry and Uses of Molybdenum; Barry, H. F., Mitchell, P. C. H., Eds.; Climax Molybdenum Co.: Ann Arbor, MI, 1982; pp 179-186.

(59) Weller, S. W. Energy Fuels 1994, 8, 415-420.

(60) Song, C.; Saini, A. K.; Y oneyama, Y. Fuel 2000, 79, 249-261.

(61) Vittal, M.; Boehman, A. L. Energy Fuels 1996, 10, 1028-1029.

(62) Lastra, B.; Garcia, R.; Moinelo, S. R. Energy Fuels 1997, 11, $411-415$ 622

(63) Warzinski, R. P.; Bockrath, B. C. Energy Fuels 1996, 10, 612-

(64) Schroeder, K.; Bockrath, B. C.; Miller, R.; Davis, H. Energy Fuels 1997, 11, 221-226.

(65) Zhang, C.; Lee, C. W.; Keogh, R. A.; Demirel, B.; Davis, B. H

Fuel 2001, 80, 1131-1146.

(66) Le, J . M.; Vimalchand, P.; Cantrell, C. E.; Davies, O. L. Proc U.S. DOE Contractor's Rev. Conf. 1992, 35.

(67) Vimalchand, P.; Le, J . M.; Cantrell, C. E.; Davies, O. L. Proc U.S. DOE Contractor's Rev. Con,. 1992, 175. 
Turkey's low-rank coal reserves exceed eight billion tons and most of these have high sulfur, high volatile matter and high ash contents. ${ }^{71}$ Therefore direct combustion of these solid fuels creates extreme pollution. Direct hydroliquefaction by using appropriate catalysts al so reduces sulfur content of oil and other liquefaction products via hydrodesulfurization reactions and therefore is one al ternative to obtain relatively clean liquid fuels and feedstocks for various chemical industries. When water soluble (e.g., ammoniumheptamolybdate: AHM) or organic soluble molybdenum compounds are dispersed in coal pores and on surfaces, they will react with the $\mathrm{H}_{2} \mathrm{~S}$ evolving and/or other forms of sulfur during the heat treatment applied to high-sulfur coal in the presence of hydrogen gas and will eventually be transformed into $\mathrm{MoS}_{2}$, the high-performance hydrodesulfurization and dissolution catalyst. ${ }^{50,51}$ It has been shown that other molybdenum catalysts such as molybdenum hexacarbonyl and/or molybdenum carbide, 63 phosphomolybdic acid and $\mathrm{Ni}$ or Co phosphomolybdates ${ }^{35-37}$ and bimetallics of Mo with Co or Ni supported on al umina or carbon ${ }^{51,56}$ foll owing sulfidation also had similar performances. Zhan and Givens stated that the water soluble AHM impregnated coal samples (subbituminous Wyodak Black Thunder) were as active as and much less expensive than the corresponding organic soluble precursor impregnated coal samples during hydroliquefaction. ${ }^{18}$

In this study, one sub-bituminous coal and one lignite both having high sulfur contents were directly hydroliquefied. In some of the liquefaction experiments, coal samples impregnated with ammonium heptamolybdate (AHM) as a catalyst precursor were used. The effects of the type of coal, the vehicle solvent, the catalyst, the mineral matter of coal, and the reaction temperature on product distribution and on the fate of organic sulfur were discussed.

\section{Experimental Section}

Gediz sub-bituminous coal and Çayirhan lignite were liquefied in this study. Their proximate and ultimate analysis data are given in Table 1. The coals were ground to pass 60 mesh, dried at $50{ }^{\circ} \mathrm{C}$ under reduced nitrogen pressure (no air) until moisture contents fell below $3 \%$, sealed in glass ampules under nitrogen gas, and kept at $-20{ }^{\circ} \mathrm{C}$ until utilization in the liquefaction experiment. All solvents and chemicals were bought from Merck and used as received.

The catalyst precursor, ammoniumheptamolybdate (AHM), $\left(\mathrm{NH}_{4}\right)_{6} \mathrm{Mo}_{7} \mathrm{O}_{24} \cdot 2 \mathrm{H}_{2} \mathrm{O}(1.0047 \mathrm{~g})$, was dissolved in $30 \mathrm{~mL}$ of distilled water and added onto $100 \mathrm{~g}$ of dry coal dropwise while the coal was effectively mixed with a spatula. This addition took about $30 \mathrm{~min}$ after which the coal was dried at $50{ }^{\circ} \mathrm{C}$ under reduced nitrogen pressure until the moisture content fell below $3 \%$. The incipient wetness water value of all coal samples were adjusted between 2 and $3 \%$. A bulk of ground coal was subjected to catalyst precursor impregnation with the above procedure and with the same relative amounts of AHM to coal and the impregnated coal samples after drying under reduced nitrogen pressure, were sealed in many glass ampules

(68) Swanson, A. Proc. U.S. DOE Contractor's Rev. Conf. 1992, 107. (69) Comolli, A. G.; Lee, L. K.; Pradhan, V. R.; Stalzer, R. H. Proc. Coal Liq. Gas Conv. Contractor's Rev. Conf. 1994, 19.

(70) Lee, L. K.; Pradhan, V. R.; Stalzer, R. H.; J ohanson, E. S.; Comolli, A. G. Proc. Coal Liq. Gas Conv. Contractor's Rev. Conf. 1994, 33.

(71) Kural, O. Coal; Istanbul, 1991; pp 294-332.
Table 1. Proximate and Ultimate Analytical Data of Coals

\begin{tabular}{lcc}
\hline & \multicolumn{2}{c}{ coal } \\
\cline { 2 - 3 } & Gediz & Çayirhan \\
\hline calorific value (kj/kg) & 22598 & 16074 \\
ash (wt \% dry) & 34.0 & 38.1 \\
V. M. (wt \% dry) & 32.8 & 36.8 \\
\multicolumn{1}{c}{ Elemental Analysis (wt \% Dafa) } \\
H & 78.3 & \\
N & 6.0 & 70.5 \\
S & 1.1 & 6.8 \\
Ob & 6.8 & 1.9 \\
& 7.8 & 2.1 \\
total & Forms of Sulfur (wt \% Dry) \\
pyritic & 7.6 & 18.7 \\
sulfatic & 2.9 & \\
orgb & 0.2 & 2.7 \\
a Daf: dry, ash-free. ${ }^{b}$ Calculated from difference.
\end{tabular}

under nitrogen gas so that all catalytic liquefaction experiments would be carried out with the coal samples having identical AHM dispersion and identical incipient wetness.

Samples of demineralized coals were also prepared to be used in liquefaction experiments. Three types of demineralization were applied:

Removing Cationic Components. Fifty grams of ground coal was poured into $100 \mathrm{~mL}$ of $5 \mathrm{~N} \mathrm{HCl}$ and heated at $60-70$ ${ }^{\circ} \mathrm{C}$ under nitrogen gas atmosphere for 1 day while being mixed with a magnetic stirrer. The solid coal remaining was filter ed and washed with distilled water effectively to remove all residual $\mathrm{HCl}$. Chloride test with silver nitrate solution was applied to filtrates.

Removing Clays and Cationic Components. Same procedure was applied with concentrated $\mathrm{HF}$ and then $5 \mathrm{~N}$ $\mathrm{HCl}$ being added in succession.

Removing Pyritic Components as Well as Clays and Cationic Components. Following sequential application of concentrated $\mathrm{HF}$ and $5 \mathrm{~N} \mathrm{HCl}, 5 \mathrm{~N}$ nitric acid was applied at the same temperature and duration.

After extensive washing with distilled water, all demineralized samples were dried at $50^{\circ} \mathrm{C}$ under reduced nitrogen pressure until moisture contents fell below $3 \%$, sealed into glass ampules under nitrogen gas, and kept at $-20^{\circ} \mathrm{C}$ until utilization for liquefaction experiments.

Microautoclaves of $25 \mathrm{~mL}$ volume were used in liquefaction experiments. In a typical experiment, $2.5 \mathrm{~g}$ of coal (AHM impregnated or not) and $5 \mathrm{~g}$ of solvent (if solvent had to be used) were charged into the reactor. Following sealing the reactor, air inside the reactor was swept out by succesive pressurizing (6.9 $\mathrm{MPa}$ cold) and depressurizing twice with nitrogen and twice with hydrogen gases. Finally, the reactor was pressurized with hydrogen gas (6.9 $\mathrm{MPa}$ cold) and submerged into an eutectic salt bath after fixing on a horizantally oscillating system. The bath, having a temperature of $5{ }^{\circ} \mathrm{C}$ above the desired working temperature, heats the reactor to the desired working temperature in 1-2 min. The horizantally oscillating system shakes the reactor with an amplitude of $2 \mathrm{~cm}$ at $400 \mathrm{cycles} / \mathrm{min}$. In all of the liquefaction experiments, the duration of operation was $30 \mathrm{~min}$. All liquefaction experiments were carried out twice. Therefore, various numerical quantitative data relevant to liquefied material were the mean of two corresponding values. When the difference between the two replicate values for the total conversion exceed $2 \%$ of the mean value, a third replicate experiment was performed and the two most close values out of three were used for calculations. The yield of oil + gas fractions were calculated by difference. Qualitative and quantitative gas analysis were not done except $\mathrm{H}_{2} \mathrm{~S}$. For those experiments where tetralin was used as solvent, no attempt 
Table 2. The Effect of Temperature with Different Solvent/Catalyst Combinations on the Conversion of Coals during Liquefaction ${ }^{a}$

\begin{tabular}{|c|c|c|c|c|c|c|c|c|c|}
\hline \multirow[b]{3}{*}{ system } & \multirow[b]{3}{*}{ temperature $\left({ }^{\circ} \mathrm{C}\right)$} & \multicolumn{8}{|c|}{ conversion (wt \% of daf coal) } \\
\hline & & \multicolumn{2}{|c|}{ totalc } & \multicolumn{2}{|c|}{ PASC $^{\circ}$} & \multicolumn{2}{|c|}{$\mathrm{AS}^{\mathrm{C}}$} & \multicolumn{2}{|c|}{ oil + gas $^{d}$} \\
\hline & & GED & $\overline{C A Y}$ & GED & CAY & GED & CAY & GED & CAY \\
\hline \multirow[t]{4}{*}{$\mathrm{H}_{2}$} & 300 & 21.5 & 7.7 & 14.5 & 2.3 & 6.6 & 1.5 & $<1$ & 3.9 \\
\hline & 350 & 30.6 & 20.0 & 18.1 & 3.2 & 7.3 & 3.5 & 5.2 & 13.3 \\
\hline & 400 & 89.7 & 74.2 & 30.0 & 20.2 & 47.5 & 24.0 & 12.2 & 30.0 \\
\hline & 450 & 81.9 & 73.0 & 10.1 & 5.2 & 22.4 & 16.5 & 49.4 & 51.3 \\
\hline \multirow[t]{4}{*}{$\mathrm{H}_{2}$ /tet } & 300 & 34.0 & 9.2 & 18.4 & 3.1 & 9.9 & 1.5 & 5.7 & 4.6 \\
\hline & 350 & 55.1 & 28.8 & 34.2 & 11.2 & 14.8 & 12.9 & 6.1 & 4.7 \\
\hline & 400 & 95.0 & 75.1 & 32.8 & 18.7 & 32.1 & 20.2 & 30.1 & 36.2 \\
\hline & 450 & 97.0 & 85.1 & 12.2 & 9.2 & 17.5 & 15.0 & 67.3 & 60.9 \\
\hline \multirow[t]{4}{*}{$\mathrm{H}_{2} / \mathrm{AHM}$} & 300 & 26.5 & 8.5 & 17.2 & 0.5 & 9.0 & 1.0 & 0.3 & 7.0 \\
\hline & 350 & 36.0 & 36.3 & 19.5 & 4.5 & 15.6 & 5.3 & 0.9 & 26.5 \\
\hline & 400 & 93.3 & 85.4 & 39.8 & 9.9 & 47.9 & 24.0 & 5.6 & 51.5 \\
\hline & 450 & 93.5 & 83.2 & 23.8 & 4.4 & 28.6 & 12.2 & 41.1 & 66.6 \\
\hline \multirow[t]{4}{*}{$\mathrm{H}_{2} /$ tet/AHM } & 300 & 36.8 & 9.2 & 10.5 & 2.2 & 17.6 & 1.6 & 8.7 & 5.4 \\
\hline & 350 & 65.6 & 37.6 & 14.9 & 4.1 & 33.5 & 9.8 & 17.2 & 23.7 \\
\hline & 400 & 98.6 & 88.5 & 18.4 & 15.0 & 45.9 & 22.5 & 34.3 & 51.0 \\
\hline & 450 & 98.3 & 85.0 & 10.5 & 3.4 & 18.2 & 11.1 & 69.6 & 70.5 \\
\hline
\end{tabular}

a Single-stage liquefaction, $30 \mathrm{~min} .{ }^{\mathrm{b}}$ Daf: dry, ash-free. ${ }^{\mathrm{c}} \mathrm{GED}$ : Gediz coal. CAY: Çayirhan lignite. AS: asphaltene. PAS: preasphaltene. d Calculated from difference.

was made to recover tetralin in order not to remove some other volatile oil products as well, however, the oil + gas yield values in corresponding tables did not include the solvent contributions because they were calculated by difference.

When the liquefaction operation time was over, the reactor was taken out of salt bath and immediately plunged into a cold water bath. The gas in the reactor was bubbled through a cadmi um acetate sol ution so that $\mathrm{H}_{2} \mathrm{~S}$ reacted with $\mathrm{Cd}^{2+}$ and precipitated quantitatively as CdS. Gravimetric analysis of precipitated $\mathrm{CdS}$ gave the $\mathrm{H}_{2} \mathrm{~S}$ yiel d from liquefaction process. The slurry content of the reactor was taken out by n-hexane into an extraction thimble and succesively extracted in a soxhelet apparatus with n-hexane, toluene, and tetrahydrofuran; oil, asphaltene (AS), and preasphaltene (PAS) were the material solubilized in these three solvents, respectively. The mass of oil + gas products were cal culated by subtracting the total mass of asphaltene + preasphaltene + char (residue) from the mass of original dry coal subjected to liquefaction. Sulfur contents of oil, asphaltene, preasphaltene and char were analyzed by using LECO-SC132 instrument. Oil analysis were carried out by using GC-MSD (HP-5970 MSD coupled to a HP-5980 GC). MSD was equipped with a quadrupole analyzer and operated in electron impact (70 eV) mode. The GC of the GC-MSD system was equipped with a TC-17 50\%: $50 \%$ phenyl-methyl si loxane column $(30 \mathrm{~m} \times 0.32 \mathrm{~mm}$ i.d.; 0.5 $\mu \mathrm{m}$ film thickness). The column oven temperature program starts at $50{ }^{\circ} \mathrm{C}$ ( $5 \mathrm{~min}$ hold) and then increases up to $280{ }^{\circ} \mathrm{C}$ with a $4{ }^{\circ} \mathrm{C} / \mathrm{min}$ ramp. The oven temperature was hold at this final value for $15 \mathrm{~min}$.

\section{Results and Discussion}

1. Variation of Processing Temperature in the Presence and Absence of Solvent and Catalyst. Both coals were subjected to liquefaction with various solvent/catalyst combinations at four different processing temperatures, namely, at $300,350,400$, and $450^{\circ} \mathrm{C}$. The product distributions and the corresponding total conversions are given in Table 2.

The first observation from Table 2 is that dissolution of coal matrix in Gediz coal starts at comparatively lower temperatures than those of Çayirhan lignite, and at all conditions the total conversion values of Gediz coal are higher than those of Çayirhan lignite.

Asphaltene and preasphaltene fractions dominate when Gediz coal is liquefied at temperatures of $400{ }^{\circ} \mathrm{C}$ or below, indicating that the original coal matrix has comparatively large units interconnected or cross-linked by weak bonds; presumably at least some of them are sulfide type of bonds. On the other hand, transformation of these preasphaltene and asphaltene molecules into smaller molecules (oil) is not easy and significant transformations only occur at $450{ }^{\circ} \mathrm{C}$ indicating that weak $\mathrm{S}-\mathrm{S}$ or $\mathrm{S}-\mathrm{C}$ type of bonds are no longer present in these asphaltene and preasphaltene molecules.

One other observation regarding liquefaction of Gediz coal is that without any solvent and added catalyst, total conversion is al most $90 \%$ at $400^{\circ} \mathrm{C}$, though substantial oil + gas formation occurs at $450^{\circ} \mathrm{C}$. This indicates that some of the mineral matter components together with high sulfur content transform into catalyst type material under processing conditions but still quenching of active radicals formed at this temperature is not fast enough because the total conversion decreased to $81.9 \%$ due to the retrogressive reactions.

When Gediz coal is liquefied with AHM in the absence of added solvent, small increases in total conversion are noted, whereas oil + gas yields are decreased compared to no catalyst case. This might be an indication that $\mathrm{AHM}$ is not effective enough in transferring sufficient active hydrogen from gas phase to the radicalic fragments cleaved off coal structure and the asphal tene and preasphaltene molecules formed from Gediz coal. On the other hand, when tetralin was used as solvent (no AHM) total conversion value increased to $97 \%$ and oil + gas yield also increased to $67.3 \%$ at $450{ }^{\circ} \mathrm{C}$; i.e., using tetralin, in addition to swelling the coal, was effective in transferring hydrogen and stabilizing small fragments which were cleaved off coal and asphaltene and preasphaltene molecules. This observation is consistent with the previous findings that tetralin behaves as an effective stabilizator in thermaly stressed jet fuels via its hydrogen donor property where there is no catalyst. ${ }^{74}$

(72) Naumann, A. W.; Behan, A. S.; Thorsteinson, E. M. Proceedings of the 4th International Conference on Chemistry and Uses of Molybdenum; 1982; p 313.

(73) Lopez, J .; Pasek, E. A.; Cugini, A. V. U.S. Patent 4, 762, 812, August 9, 1988.

(74) Coleman, M.; Schobert, H.; Song, C. Chemistry in Britain; The Royal Chemistry Society: London, 1993; Vol. 29, pp 760-762. 
Table 3. Sulfur Content of the Product Fractions Obtained from Liquefaction of Coals

\begin{tabular}{|c|c|c|c|c|c|c|c|c|c|c|c|}
\hline \multirow[b]{3}{*}{ system } & \multirow[b]{3}{*}{ temperature $\left({ }^{\circ} \mathrm{C}\right)$} & \multicolumn{10}{|c|}{ sulfur content (wt \% of the fractions except Gas) } \\
\hline & & \multicolumn{2}{|c|}{ residue } & \multicolumn{2}{|c|}{ PAS } & \multicolumn{2}{|c|}{ AS } & \multicolumn{2}{|c|}{ oila } & \multicolumn{2}{|c|}{ gas $^{b}$} \\
\hline & & GED & CAY & GED & CAY & GED & CAY & GED & CAY & GED & CAY \\
\hline \multirow[t]{4}{*}{$\mathrm{H}_{2}$} & 300 & 6.8 & 5.7 & 6.4 & $\mathrm{nd}^{\mathrm{c}}$ & nd & nd & nd & nd & 6.4 & 3.4 \\
\hline & 350 & 6.4 & 5.9 & 5.5 & 5.2 & 5.9 & nd & 15.6 & nd & 13.1 & 6.4 \\
\hline & 400 & 6.2 & 7.3 & 3.9 & 2.1 & 4.4 & 1.3 & 8.4 & $<0.1$ & 28.6 & 23.0 \\
\hline & 450 & 5.3 & 6.5 & 2.7 & 1.8 & 2.7 & 1.5 & 2.7 & 0.3 & 51.3 & 31.3 \\
\hline \multirow[t]{4}{*}{$\mathrm{H}_{2} /$ tet } & 300 & 7.2 & 5.6 & 4.9 & 5.6 & 4.3 & nd & 17.3 & nd & 2.7 & $<1$ \\
\hline & 350 & 6.8 & 5.8 & 5.2 & 3.8 & 5.7 & 3.8 & 29.8 & 0.1 & 5.2 & 6.0 \\
\hline & 400 & 6.2 & 7.4 & 3.7 & 2.4 & 4.5 & 2.0 & 12.7 & 0.8 & 15.5 & 15.9 \\
\hline & 450 & 6.8 & 7.7 & 2.7 & 2.9 & 4.1 & 1.1 & 4.8 & 0.8 & 31.4 & 26.7 \\
\hline \multirow[t]{4}{*}{$\mathrm{H}_{2} / \mathrm{AHM}$} & 300 & 8.3 & 5.9 & 5.6 & nd & nd & nd & nd & nd & 5.7 & $<1$ \\
\hline & 350 & 6.3 & 5.9 & 5.9 & 3.5 & 6.1 & 4.6 & nd & 1.6 & 13.5 & 8.3 \\
\hline & 400 & 6.5 & 8.5 & 3.7 & 2.8 & 4.8 & 1.7 & 9.0 & $<0.1$ & 32.8 & 19.4 \\
\hline & 450 & 7.0 & 8.7 & 2.2 & 2.1 & 2.8 & 1.4 & $<1$ & 0.1 & 48.0 & 31.7 \\
\hline \multirow[t]{4}{*}{$\mathrm{H}_{2} / \mathrm{tet} / \mathrm{AHM}$} & 300 & 7.6 & 5.9 & 5.5 & 4.0 & 4.9 & nd & 9.3 & nd & 2.3 & $<1$ \\
\hline & 350 & 5.9 & 6.0 & 5.3 & 3.4 & 4.6 & 3.7 & 18.5 & 4.1 & 6.2 & 3.4 \\
\hline & 400 & 6.4 & 8.1 & 3.5 & 2.8 & nd & 2.4 & nd & 1.8 & 11.6 & 4.9 \\
\hline & 450 & 7.6 & 8.9 & 2.8 & 3.8 & 5.0 & 2.2 & 4.7 & 0.9 & 21.4 & 11.0 \\
\hline
\end{tabular}

a Calculated from difference. ${ }^{b}$ wt \% of total coal sulfur converted to $\mathrm{H}_{2} \mathrm{~S}$ during liquefaction (assuming $\mathrm{H}_{2} \mathrm{~S}$ is the only $\mathrm{S}$ containing compound in the gas phase. ${ }^{c}$ nd: not determined.

On the other hand, in the present liquefaction system it might be probable that the mineral matter of Gediz coal, which presumably has been transformed into active catalyst forms by sulfidation with its own sulfur forms throughout the liquefaction, would have played an additional role in providing this high conversion because there was hydrogen gas in the reactor.

Çayirhan lignite with its relatively lower total sulfur and organic sulfur contents when compared with Gediz coal, behaves rather differently in hydroliquefaction. In no solvent, no added catalyst case, substantial conversion takes place at and above $400{ }^{\circ} \mathrm{C}$. At all temperatures in this no-solvent, no-added-catalyst case, the most abundant fraction of products is oil + gas indicating that many smaller units are attached to the main structural frame by rather weak bonds. Since the oxygen content of this lignite is much more than that of Gediz coal, one can argue that a significant portion of this oxygen content, besides the carboxyl groups, forms those relatively weak bonds, bridges, and cross links of hydrogen bonded phenolic hydroxyls in the lignite structure. The abundant phenolic compounds in the oil fraction derived from this lignite supports this argument.

Although the mineral matter of Çayirhan lignite is al so effective in catalyzing hydroliquefaction reactions, the extent is less than the corresponding effect in Gediz coal. In contrast to Gediz coal's behavior, AHM without added solvent, is effective in Çayirhan lignite increasing both total conversion and oil + gas yield substantially. It was well-known that low-rank coals with their high oxygen functional group concentrations adsorb multicharged metal cations through an ion exchange mechanism and this property has been used for dispersing metal catalysts accross a coal surface prior to liquefaction. ${ }^{75,76}$ Since the oxygen functionalities are abundant in Çayirhan lignite, a more well-dispersion of the catalyst precursor compared to Gediz coal's case should be the main reason for this observation. On the other hand, addition of tetralin helps little in improving liquefaction reactions which is also contrary to Gediz coal's corresponding case.

(75) Hatswell, M. R.; J ackson, W. R.; Larkins, F. P.; Marshall, M.; Rash, D.; Egers, E. R. Fuel 1980, 59, 442-444.

(76) Lafferty, C. J .; Hobday, M. D. Fuel 1990, 69, 79-82.
In a recent study, ${ }^{77}$ Çayirhan lignite (called Beypazari lignite in the relevant publication) was liquefied in tetralin under nitrogen atmosphere. Various catalysts including $\mathrm{Mo}(\mathrm{CO})_{6}$ were used in the liquefaction. The finely ground lignite and the catalyst were mixed in solid form prior to liquefaction. The maximum processing temperature was $425^{\circ} \mathrm{C}$. In all of the liquefaction experiments, oil + gas yiel ds were less than $50 \mathrm{Wt} \%$ of daf coal. When these values are compared with the maximum oil + gas yields of the present study ( $70.5 \mathrm{Wt}$ $\%$ of daf coal) which are substantially higher than the yields achieved in the former study, one can conclude that the well-dispersion of the catalyst due to the impregnation of the catalyst precursor onto the lignite should be the main reason for this discrepancy. Hydrogen gas used in our liquefaction experiments might be an additional factor via regenerating reacted tetralin and also taking a part in hydrogenolysis and hydrogenation reactions.

2. The Distribution of Sulfur in Liquefaction Products. Table 3 summarizes sulfur and $\mathrm{H}_{2} \mathrm{~S}$ analysis. $\mathrm{H}_{2} \mathrm{~S}$ formations were abundant in liquefaction of both coals when solvent was not used. In Gediz coal, this amounts to half of the total sulfur in coal, whereas in Çayirhan lignite, the corresponding ratio is roughly onethird. Tetralin decreases $\mathrm{H}_{2} \mathrm{~S}$ yield in liquefaction of both coals to a certain degree. In the literature, there is also an observation regarding reaction of tetralin with $\mathrm{H}_{2} \mathrm{~S} .{ }^{78}$ One other observation regarding $\mathrm{H}_{2} \mathrm{~S}$ formation is the effect of AHM especially when used with tetral in. AHM decreases $\mathrm{H}_{2} \mathrm{~S}$ yield additionally. This may be attributed to the reaction of AHM with some of the $\mathrm{H}_{2} \mathrm{~S}$ formed and/or with some sulfur functionalities in coal prone to $\mathrm{H}_{2} \mathrm{~S}$ formation under applied conditions. The sulfur contents of oils obtained from liquefaction of both coals are very low in $\mathrm{H}_{2} / \mathrm{AHM}$ system; i.e., when tetralin is not present. This may be an indication of preferential reaction of $\mathrm{AHM}$ with $\mathrm{H}_{2} \mathrm{~S}$ and/or other sulfur functionalities in liquid-phase rather than with $\mathrm{H}_{2} \mathrm{~S}$ in the gas phase because $\mathrm{H}_{2} \mathrm{~S}$ yields in $\mathrm{H}_{2}$ and $\mathrm{H}_{2} / \mathrm{AHM}$ systems are al most equal; for Çayirhan lignite the corresponding

(77) Karaca, H.; Ceylan, K.; Olcay, A. Fuel 2001, 80, 559-564.

(78) Winans, R. E.; J oseph, J . T.; Fisher, R. B. Prepr. Pap.-Am. Chem. Soc., Div. Fuel Chem. 1994, 39, 434-437. 
Table 4. The Conversion of Demineralized Coals during Liquefaction at $400{ }^{\circ} \mathrm{C}$ in Single Stage Process (30 min)

\begin{tabular}{|c|c|c|c|c|c|c|c|c|c|c|}
\hline \multirow[b]{2}{*}{ demineralization } & \multirow[b]{2}{*}{ liquefaction system } & \multicolumn{2}{|c|}{ total conversiona } & \multicolumn{2}{|c|}{ PAS $^{a}$} & \multicolumn{2}{|c|}{$\mathrm{AS}^{\mathrm{a}}$} & \multicolumn{2}{|c|}{$\mathrm{oil}+$ gas $^{\mathrm{a}, \mathrm{b}}$} & \multirow{2}{*}{$\begin{array}{c}\text { Sg/St } \% c \\
\text { GED }\end{array}$} \\
\hline & & GED & CAY & $\overline{G E D}$ & CAY & GED & CAY & GED & CAY & \\
\hline & $\mathrm{H}_{2}$ & 89.7 & 74.2 & 30.0 & 20.2 & 47.5 & 24.0 & 12.2 & 30.0 & 28.6 \\
\hline $\mathrm{HCl}$ & $\mathrm{H}_{2}$ & 69.1 & 47.9 & 21.3 & 13.9 & 33.2 & 20.2 & 14.6 & 13.8 & 34.6 \\
\hline $\mathrm{HCl} / \mathrm{HF}$ & $\mathrm{H}_{2}$ & 90.9 & 68.6 & 22.1 & 16.2 & 30.0 & 14.3 & 38.8 & 38.1 & 31.8 \\
\hline $\mathrm{HCl} / \mathrm{HF} / \mathrm{HNO}_{3}$ & & 17.6 & 10.4 & 4.3 & 2.7 & 3.1 & 2.2 & 10.2 & 5.5 & 6.5 \\
\hline & $\mathrm{H}_{2}$ /tet & 95.0 & 75.1 & 32.8 & 18.7 & 32.1 & 20.2 & 30.1 & 36.2 & 15.5 \\
\hline $\mathrm{HCl}$ & $\mathrm{H}_{2}$ /tet & 86.4 & 67.1 & 23.7 & 17.3 & 29.0 & 18.4 & 33.7 & 31.4 & 22.4 \\
\hline $\mathrm{HCl} / \mathrm{HF}$ & $\mathrm{H}_{2}$ /tet & 92.1 & 72.2 & 16.9 & 15.6 & 36.4 & 19.6 & 38.8 & 37.0 & 12.8 \\
\hline $\mathrm{HCl} / \mathrm{HF} / \mathrm{HNO}_{3}$ & $\mathrm{H}_{2}$ /tet & 74.5 & 59.7 & 22.4 & 9.2 & 26.6 & 8.3 & 25.5 & 42.2 & 4.5 \\
\hline
\end{tabular}

a wt \% (daf). ${ }^{b}$ Calculated from difference. ${ }^{c}$ wt $\%$ of total coal sulfur converted to $\mathrm{H}_{2} \mathrm{~S}$.

values are $31.3 \%$ and $31.7 \%$ and for Gediz coal the corresponding values are $51.3 \%$ and $48.0 \%$, respectively (450 ${ }^{\circ} \mathrm{C}$ treatments).

The sulfur contents of oils derived from Gediz coal in the presence of tetralin are rather high; $4.8 \%$ in $\mathrm{H}_{2}$ /tet and $4.7 \%$ in $\mathrm{H}_{2} /$ tet/AHM systems. On the other hand, tetralin or a similar hydrogen donating solvent is necessary to achieve high oil yields (refer Table 2). Therefore, to obtain high yields of oil with low sulfur contents from Gediz coal, a deep desulfurization should be applied to the oil produced in $\mathrm{H}_{2}$ /tet/AHM system oils obtained from liquefaction of Çayirhan lignite has less sulfur contents when compared with oils from Gediz coal. Again, in the presence of tetralin less $\mathrm{H}_{2} \mathrm{~S}$ is formed. On the other hand, Çayirhan lignite yielded high oil + gas products with $\mathrm{H}_{2} / \mathrm{AHM}$ system (refer Table 2). This lignite can be liquefied in a single stage producing oil of sulfur content less than $1 \%$.

It has been stated that $\mathrm{H}_{2} \mathrm{~S}$ is a good hydrogen donor and in the presence of $\mathrm{H}_{2}$ can play an autocatalytic effect in liquefaction reactions. ${ }^{7,79,80}$ Recent research results indicate that a concentration of $\mathrm{H}_{2} \mathrm{~S}$ in $\mathrm{H}_{2}$ around $3 \%$ (by weight) is optimum for sulfidation of molybdenum to form an active hydrodesulfurization and hydrogenation catalyst during liquefaction of Mo-impregnated coals. ${ }^{35,36,63}$ The amounts of $\mathrm{H}_{2} \mathrm{~S}$ formed during liquefaction of both Gediz coal and Çayirhan lignite were far more in excess of the amount dictated by the amount of hydrogen gas charged into the reactor. In direct liquefaction of these high sulfur coals, excess $\mathrm{H}_{2} \mathrm{~S}$ formed can be recycled to be used in the liquefaction process or it can be partially or completely converted into hydrogen gas by an economical photocatalytic process devel oped recently ${ }^{81}$ and then recyled to be used in the liquefaction process.

3. Effect of Mineral Matter on Liquefaction. When low-rank coals are treated with $\mathrm{HCl}$, exchangeable cations which are mainly attached to carboxylate groups are removed and therefore free carboxylic acid groups are formed. J oseph and Forrai have showed that alkali and earth alkali type of metal cations had retarding effect on liquefaction. 82 Therefore, removal of such cations may be beneficial for liquefaction. However, there are also observations, mainly from model compound studies, that free carboxylic acid groups may undergo condensation reactions forming anhydride and ester type of linkages throughout heat treatment of coal

(79) Sondreal, E. A.; Warrack, G. W.; Stenberg, V. I. Fuel 1982, 61, 925-938.

(80) Lambert, J. M., J r. Fuel 1982, 61, 777-778.

(81) Tambwekar, S. V.; Subrahmanyam, M. Int. J . Hydrogen Energy 1997, 22, 959-965.

(82) J oseph, J . T.; Forrai, T. R. Fuel 1992, 71, 75-80. which are more prone to take a part in radical reactions at higher temperatures to form cross linkages and such behavior would retard liquefaction reactions. 83,84

The product distributions from liquefaction of demineral ized Gediz coal and Çayirhan lignite are given in Table 4. In the first group of liquefaction experiments, acid-pretreated coal and lignite samples were treated with hydrogen in the absence of solvent. The overall conversions in hydroliquefaction of $\mathrm{HCl}$-pretreated $\mathrm{Ge}$ diz coal and Çayirhan lignite were retarded substantially. In Gediz coal this retardation was mainly for dissolution reactions toward forming AS and PAS while there was a slight increase in oil + gas yield presumably due to release of some small trapped coal molecules during $\mathrm{HCl}$ treatment and/or increased decarboxylation during the heat treatment in liquefaction. On the other hand, in liquefaction of $\mathrm{HCl}$-pretreated Çayirhan lignite, this retardation was much more pronounced with subsequent decreases in both overall and oil + gas yields. The high oxygen functionalities in this lignite, when converted into free forms foll owing $\mathrm{HCl}$ treatment, should be responsible for the condensation and subse quent cross-linking reactions. ${ }^{83,84}$

Following $\mathrm{HF} / \mathrm{HCl}$ treatment, total conversion in liquefaction of pretreated Gediz coal remained roughly the same, whereas oil + gas yield increased 3-fold (compared to untreated coal) when no solvent was used. This indicates that $\mathrm{HF} / \mathrm{HCl}$ treatment either activates those mineral matter in catalyzing hydrocracking reactions in this coal and/or removes some mineral matter which retards liquefaction reactions. Since HF treatment mainly removes clays from coal structure, the observed changes during liquefaction should be attributed to the removal of these material. In the the literature, one can find both enhancing ${ }^{85}$ and retarding ${ }^{86}$ observations regarding liquefaction of $\mathrm{HF} / \mathrm{HCl}$ treated coals. It has been stated that char-forming reactions catalyzed by clays (or acidic sites on coal mineral matter) may limit conversion in some liquefaction processes. ${ }^{87}$ The results obtained in this work strongly support this view. The difference in conversion values (liquefaction) of $\mathrm{HCl}$-pretreated and $\mathrm{HCl} / \mathrm{HF}$-pretreated coals indicates the catalytic role of clay minerals in

(83) Eskay, T. P.; Britt, P. F.; Buchanan, A. C. Energy Fuels 1997, $11,1278-1287$.

(84) Artok, L.; Schobert, H. H. J . Anal. Appl. Pyrol. 2000, 54, 235246.

(85) Martin, S. C.; Schobert, H. H. Prepr. Pap.-Am. Chem. Soc., Div. Fuel Chem. 1996, 41, 967.

(86) Tarrer, A. R.; Guin, J . A.; Pitts, W. S.; Henley, J . P.; Prather, J. W.; Styles, G. A. In Liquid Fuels from Coals; Ellington, R. D. Ed., Academic Press: New York, 1977; pp 45-61.

(87) Ross, D. S.; Green, T. K.; Mansoni, R.; Hum, G. P. Energy Fuels 1987, 1, 287-291. 
condensation and subsequent cross-linking reactions of free oxygen functionalities in the coal structure. The other factors contributing to the enhancement of conversions (compared to the $\mathrm{HCl}$-pretreated case) following $\mathrm{HF} / \mathrm{HCl}$ treatment of coals might be that new pores or void spaces in the coal are created by the removal of the minerals, and that these new pores improve mass transfer in liquefaction reactions. Also pyrite and other catalytic mineral material would have a higher contact area with coal structures following removal of clay material.

Treatment of coals with $\mathrm{HF} / \mathrm{HCl} / \mathrm{HNO}_{3}$ removed pyritic material as well as clays and cationic components. Liquefaction of the treated coals with $\mathrm{H}_{2}$ only were totally unsuccessful due to the lack of catalytic mineral material.

In the second group of liquefaction experiments performed with acid-pretreated coal samples, tetralin as the solvent was used in addition to hydrogen. In general, the effect of the presence of tetralin is positive with regard to conversion. The differences between the conversion values in liquefaction by using $\mathrm{H}_{2}$ and $\mathrm{H}_{2}$ / tetralin systems of both $\mathrm{HCl}$-pretreated Gediz coal and Çayirhan lignite were such that roughly 20\% more conversion took place in the presence of tetralin for both Gediz coal and Çayirhan lignite. It seems that tetralin is much more effective in quenching radicals and/or retarding condensation reactions leading to cross-linking structures. When one compares the conversions of $\mathrm{HF} / \mathrm{HCl}$-pretreated Gediz coal and Çayirhanlignite in $\mathrm{H}_{2}$ and $\mathrm{H}_{2} /$ tetralin systems, one notes that the corresponding values are almost the same in Gediz coal's case and are very similar in Çayirhan lignite's case; i.e., the presence of tetralin does not contribute any significant enhancement to the conversion values. When this observation is coupled with the corresponding observations obtained in the liquefaction of the $\mathrm{HCl}$-pretreated coals, it is most probable that tetralin is playing an effective retarding role on clay-catalyzed condensation and subsequent cross-linking reactions.

In the presence of tetralin, it is interesting to note that oil + gas yield in liquefaction of $\mathrm{HF} / \mathrm{HCl} / \mathrm{HNO}_{3}-$ pretreated Çayirhan lignite was even higher than the corresponding yield from untreated lignite. The effect of $\mathrm{HNO}_{3}$ treatment on Çayirhan lignite might be similar to the respond of an Australian brown coal where the brown coal was completely dissolved in tetrahydrofuran following the treatment with $\mathrm{HNO}_{3}{ }^{88} \mathrm{~F}$ or the time being, we have no explanation for this observation.

4. Oil Analysis. The total ionization chromatograms (TIC) of the oil fractions obtained from liquefaction of Gediz coal and Çayirhan lignite in $\mathrm{H}_{2} / \mathrm{AHM}$ systems (no solvent) are given in Figure 1. Those peaks identified from the corresponding mass spectra are numbered and named. There are many hydrocarbon compounds, such as phenolics, alkanes, cycloalkanes, aromatics, hydroaromatics, and thiophenics in these oil fractions. Sulfur containing compounds are composed of mainly benzothiophene and methyl-substituted benzothiophenes. Dibenzothiophene and its alkyl-substituted derivatives are also present. The corresponding peaks of most of these thiophenic compounds cannot be seen under numbered labels in the chromatograms due to

(88) Mae, K.; Maki, T.; Miura, K. Energy Fuels 1997, 11, 825-831.

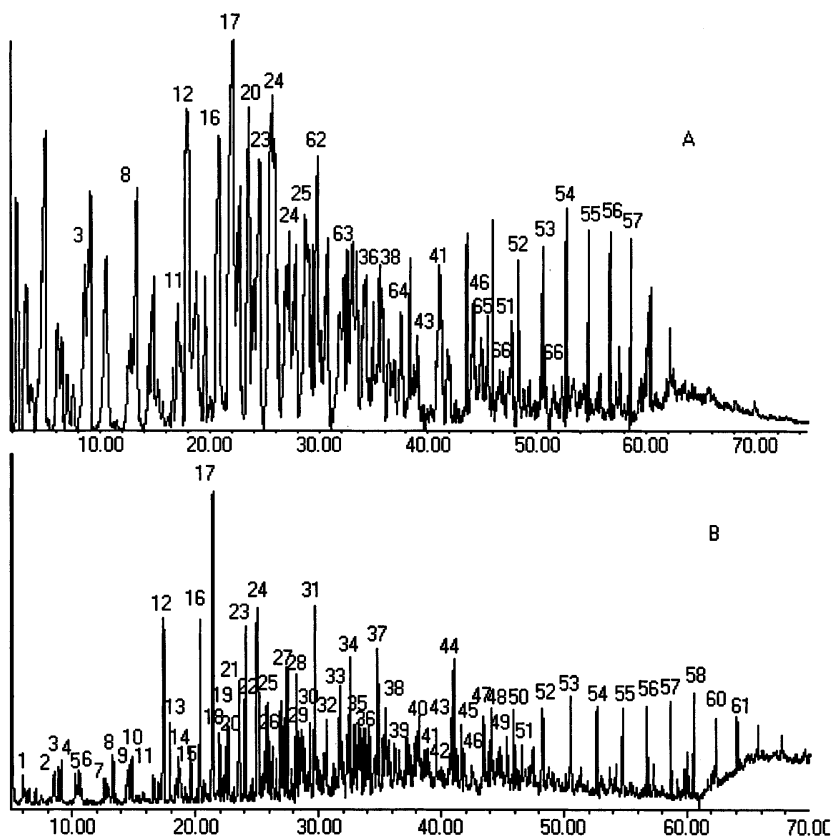

Figure 1. (A) $450{ }^{\circ} \mathrm{C} \mathrm{H}_{2} / \mathrm{AHM}$ Gediz and (B) $450{ }^{\circ} \mathrm{C} \mathrm{H}_{2} / \mathrm{AHM}$ Çayirhan oil fractions. (1) undecane, 2,7-dimethyl; (2) cyclohexane, (1-methylethyl), (3) benzene, ethyl; (4) 1,2-dimethyl benzene, (5) Hexadecane, 3-methyl; (6) benzene, 1,4-dimethyl; (7) bicyclo[3.3.1] nonane; (8) 1,2,4-trimethylbenzene, (9) o-ethyl toluene; (10) undecane, 4,6-dimethyl; (11) C3-benzene; (12) phenol; (13) benzene, cyclopropyl; (14) undecane; (15) $1 \mathrm{H}-$ Indene, 2,3-dihydro-1-methyl; (16) phenol; 2-methyl (o-cresol); (17) phenol, 3-methyl (m-cresol); (18) $1 \mathrm{H}$-indene, 2,3- di hydro4-methyl; (19) octadecane; (20) $1 \mathrm{H}$-indene, 2,3- dihydro-1methyl; (21) $1 \mathrm{H}$-indene, 2,3- dihydro-1,6-methyl; (22) phenol, 2,3-dimethyl; (23) phenol; 2,4-dimethyl; (24) phenol, 4-dimethyl; (25) naphthalene; (26) $1 \mathrm{H}$-indene, 2,3- dihydro-4,6dimethyl; (27) phenol, 2-ethyl-5-methyl; (28) phenol, 4-propyl; (29) naphthal ene, 1,2,3,4-tetrahydro-5-methyl; (30) ei cosane, 10-methyl; (31) naphthalene, 1-methyl; (32) phenol, 2-butyl; (33) $1 \mathrm{H}$-indene-5-ol, 2,3-dihydro; (34) $1 \mathrm{H}$-indene-5-ol, 2,3dihydro; (35) naphthalene, 1-ethyl; (36) naphthalene, 2,6dimethyl; (37) naphthalene, 1,4-dimethyl; (38) nonadecane; (39) 6-methyl-4-indanol; (40) pentadecane; (41) 1-benzlidene, 2,2,3,3-tetramethylcyclo; (42) naphthalene, 1-(2-propenyl); (43) n-nonadecane; (44) naphthalene; 1-(2-propenyl); (45) dibenzofuran, 4-methyl; (46) 1,1'-biphenyl, 2-ethyl; (47) 1-iodo-2methylundecane; (48) 1,1'-biphenyl, 4,4'-dimethyl; (49) benzene, 1-methyl-2-[(4-methylphenyl)]; (50) pentadecane; (51) anthracene; (52) heptadecane, 9-hexyl; (53) tricosane; (54) tetracosane; (55) heptacosane; (56) triacontane; (57) heptacosane; (58) tricosane; (59) docosane; (60) heneicosane; (61) epoxy-oxopowelline; (62) 7H-benzocycloheptene; (63) $1 \mathrm{H}$-indole; (64) acenaphthene; (65) phenanthrene, 1,2,3,4,-tetrahydro; (66) 3,4-dimethyldibenzothiophene.

their very low concentrations. Their presence and the corresponding peaks are determined by using specific ion monitoring. When the composition of oil fractions from both coals are compared, one can note that most of the components exist in both of the oils, but differing in relative quantities. In Cayirhan lignite, phenolics, of course, are much more abundant, whereas thiophenics are in trace levels.

\section{Conclusions}

Direct hydroliquefaction of low-rank coals by impregnating the catalyst or the catalyst precursor onto the coal is an effective method for obtaining clean liquid feedstocks which can be utilized in various industrial 
processes. Dispersed molybdenum catalysts are effective both in catalyzing dissolution reactions and hydrodesulfurization reactions. Therefore, in this study ammonium heptamolybdate (AHM), which is water soluble, has been chosen as catalyst precursor to be used in direct hydroliquefaction of high-sulfur coals. Since the coals to be liquefied al ready have high sulfur contents, additional sulfidation of the catalyst has not been done. In this way, it is also expected that the extent of hydrodesulfurization might be more efficient yielding low sulfur content oils.

Total conversions of more than 95\% are obtained from liquefaction of Gediz coal even without using added catalyst. Maximum conversion (98\%) and maximum oil + gas yield (70\%) from this coal were obtained by impregnating $\mathrm{AHM}$ onto coal and carrying out liquefaction in $\mathrm{H}_{2} /$ tetralin system at $450{ }^{\circ} \mathrm{C}$ for $30 \mathrm{~min}$. Under the same conditions, the other coal, Çayirhan lignite gave $85 \%$ conversion and $70.5 \%$ oil + gas yield. The impact of impregnated AHM onto coal during liquefaction under hydrogen atmosphere was superior with Çayirhan lignite, whereas with Gediz coal the corresponding effect was not significant. This has been ascribed to the fact that AHM dispersed much more efficiently accross Çayirhan lignite's structure due to an efficient ion-exchange mechanism through rich oxygen functionalities. The superior hydrodesulfurization effect of AHM on the oil fraction when used in the absence of solvent (less than $0.1 \% \mathrm{~S}$ in Çayirhan oil and less than $1 \% \mathrm{~S}$ in Gediz oil following single stage hydrogenation) is a promising finding of this study.

The observations from demineralized coal samples indicated that tetralin retards condensation of oxygen functionalities and subsequent cross-linking reactions during liquefaction. Supporting evidences to the claim that char-forming reactions catalyzed by clays (or acidic sites on coal mineral matter) may limit conversion in some liquefaction processes ${ }^{87}$ were observed.

To obtain high yields of oil with low sulfur contents from these high-sulfur coals, water soluble molybdenum compounds can be impregnated onto them and di rectly liquefied in the presence of hydrogen gas and a hydrogen donor solvent. Such oils can be deeply desulfurized and an appropriate fraction can be used in the production of high-thermal stability jet fuels.

Acknowledgment. This study has been supported by The Scientific and Technical Research Council of Turkey (TUBITAK) through the project KTCAG-126. We are grateful for the useful comments of Prof. Harold $H$. Schobert from The Energy I nstitute of Pennsylvania State University.

EF 0102667 